\title{
PENGARUH RASIO PROFITABILITAS DAN ASSET GROWTH TERHADAP NET INCOME PADA KLUB SEPAK BOLA ARSENAL FC
}

\author{
Karjiman Rahim $^{1}$, Ahmad Subaki $^{2}$, Sumardi $^{3}$ \\ $\left.{ }^{1}\right)$ Program Studi Akuntansi, Universitas Muhammadiyah Prof. Dr. Hamka \\ Email : muhamadfadliismail27@gmail.com \\ ${ }^{2}$ )Dosen Fakultas Ekonomi \& Bisnis, Universitas Muhammadiyah Prof. Dr. Hamka \\ ${ }^{3}$ )Dosen Fakultas Ekonomi \& Bisnis, Universitas Muhammadiyah Prof. Dr. Hamka
}

\begin{abstract}
This study aims to determine how the influence of return on assets, assets growth on net income. The data was obtained from the financial statements of the Arsenal FC football club which was published on the Arsenal FC soccer club website during the quarter of 2003 to the quarter of 2017 and processed using SPSS 25 software. The processing and data analysis techniques used in this study is data multiple linear regression analysis, The results of this study indicate that return on assets is partial and significantly positive effect on net income. Assets growth has a partial and significantly negative effect on net income).
\end{abstract}

Keywords; Return on Assets, Assets Growth, Net Income, FC Arsenal.

Abstrak: Penelitian ini bertujuan untuk mengetahui bagaimana pengaruh return on assets, assets growth terhadap net income. Metode yang digunakan dalam penelitian adalah metode deskriptif dengan pendekatan metode studi kasus. Data diperoleh dari laporan keuangan klub sepakbola Arsenal FC yang publikasi dari situs klub sepakbola Arsenal FC selama triwulan tahun 2003 sampai triwulan dengan 2017 dan diolah menggunakan software SPSS 25. Teknik pengolahan dan analisis data yang digunakan dalam penelitian ini adalah analisis regresi linier berganda.Hasil dari penelitian ini menunjukkan bahwa return on assets berpengaruh positif secara parsial dan signifikan terhadap net income. Assets growth berpengaruh negatif secara parsial dan signifikan terhadap net income.

Kata kunci: Return on Assets, Assets Growth, Net Income, Arsenal FC.

\section{Pendahuluan}

Sepak bola pertama kali diakui dunia sebagai salah satu cabang olah raga pada pertengahan abab ke-19 dan pada abad itu juga yang membuat terbentuknya asosiasi tertinggi sepak bola dunia (FIFA), Berdasarkan hasil rilisan FIFA 2018 (Fédération Internationale de Football Assiciation) tercatat ada 211 negara yang ikut andil dalam olahraga ini dengan membentuk liga sepak bola dan asosiasi federasi sepak bola tersendiri dinegara-negaranya. Angka pertumbuhan laba sebelum pajak secara kolektif tersebut hampir tiga kali lipat dari rekor sebelumnya di musim 2013/14. "Seperti yang diprediksi tahun lalu, transaksi siaran tiga tahun Liga Premier yang mulai berlaku di musim 2016/17 membantu mendorong pendapatan ke rekor baru. Meskipun upah meningkat sebesar 9\%, peningkatan ini tidak jauh di atas tingkat pertumbuhan pendapatan yang tercatat. http://CNBCIndonesia.com

Situs sport detik.com Liga Primer Inggris memiliki return on assets yang minus 5\% akibat dari tingginya gaji pemain-pemainnya dan neraca negatif yang dihasilkan dari ketimpangan transfer masuk dengan transfer pemain keluar. Neraca tersebut sudah menunjukan nilai yang sama sejak tahun 2009. Lima tahun telah berlalu dan situasi masih belum juga berubah. Para 
pakar ekonomi juga masih tidak yakin kalau neraca ini akan berubah pada tahun-tahun berikutnya. situs bisnis.com salah satu survei yang dilakukan BBC, menyebutkan bahwa satu dari lima klub liga inggris termaksut dalam kategori klub dengan kesehatan finansial yang begitu menyedihkan. Survei tersebut di lakukan begbies ada 68 tim yang disurvei dan berasal dari tiga divisi di bawah Premier League yaitu Championship, League One dan League Two. Tercatat 13 dari 68 klub itu memiliki masalah kesehatan keuangan yang parah. Mereka menghadapi sejumlah tuntutan serius di pengadilan mulai dari kasus gugatan perdata, keterlambatan laporan keuangan hingga neraca laporan keuangan klub yang begitu defisit atau disebut juga neraca negatif. Dikutip dari tempo.com salah satu dengan kondisi keuangan yang baik dan bahkan selama 12 tahun tidak pernah mengalami kerugian finansial. Ini disebapkan kepintaran Arsenal Football Club dalam memanajemen operasionalnya salah satu yang signifikan adalah pemanfaatan stadion dan penjualan pemain-pemain dengan harga tinggi di bursa transfer. Dikutip dari situs bola.bisnis.com Arsenal Football Club mengumumkan laba sesudah pajak senilai 35 juta pounds atau sekitar Rp 665,0 miliar. Arsenal FC mencapai angka itu pada periode 2016-2017. Net Income Arsenal FC tersebut mengalami kenaikan 32, juta pounds atau sekitar Rp 600, miliar dibandingkan musim sebelumnya 2015-2016. Jumlah tersebut tidak sebanding dengan net income yang di raih Arsenal FC pada musim 2015-2016 yang berkisar 2 juta pounds atau sekitar

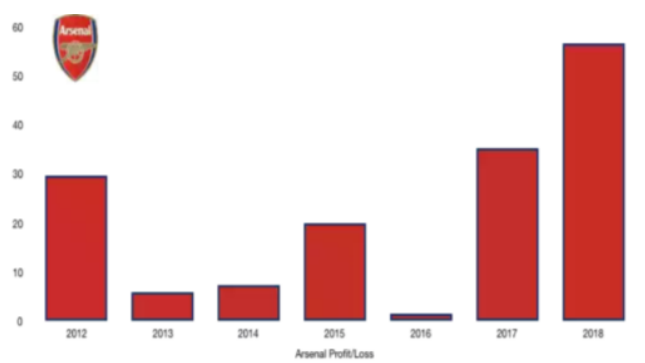

Rp 38, miliar dari periode 2015-2016. Menurut Wild et al., (2017:65) menyatakan dalam bahwa bahwa semakin besar nilai penggunan aset, menunjukkan kinerja perusahaan yang semakin baik pula, karena tingkat pengembalian investasi semakin besar.

Nilai ini mencerminkan pengembalian perusahaan dari seluruh aktiva (atau pendanaan) yang diberikan pada perusahaan, semakin tinggi tingkat pengembalian aset perusahaan maka akan semakin tinggi laba yang diperoleh perusahaan.

Permasalahan dalam penelitian ini juga diperkuat adanya research gap dari hasil penelitian terdahulu. Hal tersebut diperkuat oleh hasil penelitian yang dilakukan (Pradani, 2018) dan (Martunis, 2013) bahwa return on asset berpengaruh terhadap petumbuhan laba. Hal tersebut diperkuat oleh penelitian (Pribadi, 2016) dalam penelitianya pertumbuhan aset tetap tidak berwujud dan aset berwujud berpengaruh positif signifikan terhadap pertumbuhan laba. Dari hasil penelitian kenaikan positif laba bersih disebapkan efektifitasnya perusahaan menjalankan asetnya untuk memperoleh aset sehingga tingkat pengembalian return on assets akan berdampak positif terhadap net income. Hal tersebut diperkuat oleh hasil penelitian yang dilakukan oleh (Mohd dan Zaharudin, 2015). Hasil berbeda ditunjukkan dalam penelitian (Safitri dkk, 2018) dimana return on assets berpengaruh negatif terhadap net income.

Maka dari fenomena diatas yang dipaparkan penulis untuk mengetahui apakah rasio profitabilitas dan assets growth terjadi pengaruh yang signifikan atau tidak terjadi pengaruh yang signifikan terhadap pertumbuhan laba. Oleh sebab itu penulis akan meneliti judul "Pengaruh Rasio Profitabilitas dan Asset Growth terhadap Net Income pada Klub Sepak Bola Arsenal FC".

\section{Metodologi Penelitian}

Jenis, Metode dan Populasi

Metode yang akan digunakan adalah metode deskriptif dengan pendekatan kasus. Populasi dalam penelitian ini menggunakan data 
sekunder yang diperoleh dari laporan tahunan Arsenal FC dari triwulan tahun 2003-2017. Data sekunder tersebut diperoleh peneliti dari website resmi Arsenal FC yaitu http://www.arsenal.com.

Analisis yang digunakan dalam penelitian ini adalah analisis regresi berganda (Multiple Linier Regression Analysis). Dengan menggunakan Software Program Service Sollution (SPSS) versi 25.0. Penyelesaian penelitian ini dengan menggunakan teknik analisis kuantitatif.

\section{Pengukuran Variabel}

a. Variabel Dependen

Menurut Sugiyono (2012:59) variabel terikat merupakan variabel yang dipengaruhi atau yang menjadi akibat, karena adanya variabel bebas. Pengertian net income menurut Wild et al., (2017:98) menyatahkan bahwa laba (earnings) atau laba bersih (net income) merupakan ringkasan hasil neto dari operasi bisnis selama periode waktu tertentu. Laba merupakan bagian dari informasi perusahaan yang paling banyak diminta oleh pasar keuangan. Menurut Rahardjo (2010:83) laba bersih dapat dihitung dengan rumus sebagai berikut:

Laba Bersih = Laba sebelum pajak Pajak

b. Variabel Independent

\section{Return on Assets(ROA)}

Menurut Fahmi (2013:137) adalah rasio ini melihat sejauh mana investasi yang telah ditanamkan mampu memberikan pengembalian keuntungan sesuai yang diharapkan.

Secara matematis return on assets dapat dihitung dengan menggunakan rumus sebagai berikut:

ROA = Laba Bersih:Total Aset....(2)

2. Assets Growth

Menurut (Prasetyo 2011:110), menjelaskan pengertian pertumbuhan aktiva adalah pertumbuhan aktiva adalah perubahan (peningkatan atau penurunan) total.

Secara matematis assets growth dapat dihitung dengan menggunakan rumus sebagai berikut:

Asset Growth $=\left(\mathrm{TA}_{\mathrm{t}}-\mathrm{TA}_{\mathrm{t}-1}\right) /\left(\mathrm{TA}_{\mathrm{t}-1}\right) \ldots .(3)$

\section{Teknik Analisis Data}

Adapun penjelasan mengenai teknik pengolahan dan analisis data adalah :

\section{Uji Hipotesis.}

Metode analisis regresi linear berganda adalah metode statistik untuk menguji hubungan antara beberapa variabel bebas terhadap satu variabel terikat. Dalam penelitian ini menggunakan model regresi linear berganda, yaitu regresi linear dengan beberapa variabel prediktor (bebas) terhadap variabel tidak bebas (Supardi, 2013:239).

\section{Hasil dan Pembahasan \\ Uji Statistik $t$}

Uji secara parsial untuk menguji pengaruh masing-masing variabel independen (X) terhadap variabel dependen (Y). Kriteria keputusan uji hipotesis secara parsial didasarkan pada hasil perbandingan atau tingkat signifikansinya $t_{\text {hitung }}$ dengan $t_{\text {tabel }}$ pada tingkat keyakinan 95\% $(\alpha=0,05)$. Untuk menentukan t-tabel dalam penelitian ini dengan ketentuan tingkat signifikasi $\alpha=$ 0,05 degree of freedom $\mathrm{df}=60-2$, maka diperoleh nilai t-tabel $=2.002$.

Pada tabel 1 di bawah ini disajikan hasil uji regresi secara parsial (uji t) dengan menggunakan SPSS:

1. Berdasarkan hasil tabel uji regresi $\mathrm{t}$ di atas, return on assets $\left(\mathrm{X}_{1}\right)$ memiliki $t_{\text {hitung }}(44,248)>t_{\text {tabel }}(2.002)$ dengan taraf signifikansi sebesar $0,000<$ 0,05, maka $\mathrm{H}_{1}$ diterima, yang artinya secara parsial return on assets memiliki pengaruh signifikan terhadap net income. 


\section{Tabel 1: Uji Statistik t} Coefficients $^{\mathrm{a}}$

\begin{tabular}{|c|c|c|c|c|c|c|}
\hline \multirow[b]{2}{*}{ Model } & & \multicolumn{2}{|c|}{ Unstandardized Coefficients } & \multirow{2}{*}{$\begin{array}{c}\text { Standardized } \\
\text { Coefficients } \\
\text { Beta } \\
\end{array}$} & \multirow[b]{2}{*}{$\mathrm{T}$} & \multirow[b]{2}{*}{ Sig. } \\
\hline & & B & Std. Error & & & \\
\hline \multirow[t]{3}{*}{1} & (Constant) & 2141.997 & 580.888 & & 3.687 & .001 \\
\hline & Return on Assets & 725137.093 & 16387.943 & .936 & 44.248 & .000 \\
\hline & Assets Growth & -11358.466 & 2136.971 & -.112 & -5.315 & .000 \\
\hline
\end{tabular}

a. Dependent Variable: Net Income

Sumber : Output SPSS Versi 25.0, 2019

2. Berdasarkan hasil tabel uji regresi $t$ di atas, assets growth $\left(\mathrm{X}_{2}\right)$ memiliki $\mathrm{t}_{\text {hitung }}(-5.315)>\mathrm{t}_{\text {tabel }}(-2.002)$ dengan taraf signifikansi sebesar $0,000<$ 0,05 , maka $\mathrm{H}_{2}$ diterima, yang artinya secara parsial assets growth memiliki pengaruh signifikan terhadap net income.

\section{Interpretasi}

1. Pengaruh return on assets terhadap net income.Pengaruh positif yang ditunjukan return on assets sesuai dengan teori yang dikemukakan oleh Hery (2017:193) yaitu semakin tinggi hasil pengembalian atas aset berarti semakin tinggi pula jumlah laba bersih yang dihasilkan dari setiap rupiah dana yang tertanam dalam total aset. Sehingga ditarik kesimpulan bahwa semakin besar efektivitas penggunaan return on assets dari Arsenal Football Club, semakin besar pula tingkat keuntungan yang dicapai Arsenal Football Club tersebut dan semakin baik pula posisi Arsenal Football Club tersebut dalam penggunaan aset. Hasil penelitian ini mendukung hasil penelitian sebelumnya yang telah dilakukan oleh Indayani (2017) dan Simatupang (2018), yang menyatakan bahwa return on assets berpengaruh terhadap net income.

2. Pengaruh assets growth terhadap net income.Pengaruh negatif yang ditunjukan assets growth sesuai dengan penelitian sebelumnya yang dilakukan Wardingsih, dkk (2017) yaitu kenaikan pertumbuhan aset dihubungkan dengan pertumbuhan laba bersih dengan dasar asumsi pertumbuhan mengandung risiko. Namun hasil penelitian ini tidak sejalan dengan hasil penelitian sebelumnya yang telah dilakukan oleh Bangga (2016) pertumbuhan aset berpengaruh positif terhadap pertumbuhan laba bersih Dalam penelitian ini menunjukkan pertumbuhan aset yang tinggi dapat menyebapkan kebutuhan dana yang semakin meningkat untuk mengelola kegiatan operasional, salah satu kegiatan operasional itu kenaikan dari gaji pemain sepak bola terus meningkat setiap tahunnya yang menyebapkan penurunan laba bersih Arsenal Football Club. Ini diperkuat penelitian Winarko, dkk (2017) yaitu bertambahnya aset umumnya menyebabkan laba usaha akan bertambah tinggi, namun hal ini tergantung pada kemampuan perusahaan untuk melakukan efisensi biaya, maupun kemampuan untuk mengoperasikan dan mengelola aset yang tersedia.

\section{Simpulan}

Berdasarkan pengujian hipotesis secara parsial (uji t), maka diperoleh hasil sebagai berikut: 
artinya secara parsial return on assets memiliki pengaruh signifikan terhadap net income. Bagi Arsenal FC, dalam rangka meningkatkan net income Arsenal FC dengan menggunakan aset-asetnya (aset berwujud maupun aset tidak berwujud) harus efektif dan efisien sehingga tidak terjadi kerugian. Meningkatnya kinerja aset dapat meningkatkan produksi Arsenal FC melalui merchandise, broadcasting, gate and other match day revenues pemain Arsenal FC dan melakukan efisiensi beban operasional Arsenal FC sehingga perusahaan dapat memperoleh laba yang optimal, dengan laba yang optimal diharapkan laba Arsenal FC akan terus meningkat. Assets growth memiliki pengaruh signifikan terhadap net income. Bagi Arsenal FC, dalam rangka meningkatkan pertumbuhan asetnya untuk menghasilkan laba perlurnya untuk dilihat, meningkatnya aset tersebut diperlunya pengawasan ekstra dalam pengoptimalisasi dan efisiensi kinerja aset Arsenal FC. Sebabnya aset yang meningkat akan menyebabkan juga kebutuhan dana yang semakin meningkat untuk mengelola kegiatan operasional dan disini perlunya peran internal Arsenal FC untuk mengawasi dan mengoptimalisasi efisiensi kinerja aset perusahaan sehingga menghasilkan laba.

Berdasarkan hasil penelitian dan pembahasan sebelumnya, ada beberapa saran yang diberikan oleh peneliti sebagai berikut :

1. Bagi Arsenal FC, dalam rangka meningkatkan net income Arsenal FC dengan menggunakan aset-asetnya (aset berwujud maupun aset tidak berwujud) harus efektif dan efisien sehingga tidak terjadi kerugian. Meningkatnya kinerja aset dapat meningkatkan produksi Arsenal FC melalui merchandise, broadcasting, gate and other match day revenues pemain Arsenal FC dan melakukan efisiensi beban operasional Arsenal FC sehingga perusahaan dapat memperoleh laba yang optimal, dengan laba yang optimal diharapkan

\section{laba Arsenal FC akan terus} meningkat.

2. Bagi peneliti selanjutnya disarankan untuk menambah variabel independen lainnya seperti, pemain sepakbola, intellectual capital, nilai perusahaan dan rasio keuangan lainnya, harga jual merchandise Arsenal FC, biaya operasional produksi terhadap laba bersih.

3. Bagi peneliti selanjutnya disarankan untuk menambah periode penelitian serta memperluas variabel, sampel, dan populasi penelitian agar hasil yang diperoleh nanti mempunyai manfaat dalam rangka jangka panjang dan juga menghasilkan penelitian yang lebih baik dari penelitian ini dan diperoleh hasil yang lebih maksimal.

\section{Daftar Pustaka}

Asian, A. U. (2015). Assessing the Impact of Liquidity and Profitability Ratios on Growth of Profits in Pharmaceutical Firms in Nigeria. European Journal of Accounting. Vol. 3 Issue. 10 pp. 97-114. ISSN: 2053-4086 (October) 2015.

Nigeria: Departement of Accounting, Faculty of Management Sciences, Port Harcourt, Choba University.

Bangga, M. P. (2016). Analisis Pengaruh Pertumbuhan Aset Tetap Berwujud dan Aset Tetap Tidak Berwujud terhadap Pertumbuhan Laba Klub Sepak Bola Barclays Premier League Tahun 2011-2014. Skripsi. Lampung: Program Studi Akuntansi Fakultas Ekonomi dan Bisnis Universitas Lampung Bandarlampung.

Fahmi, I. (2013). Analisis Kinerja Keuangan. Bandung: Alfabeta.

Gaol, C. J. L. (2014). A to Z Human Capital. Jakarta: Gramedia Widiasarana. 
Hery, (2017). Teori Akuntansi Pendekatan Konsep dan Analisis. Jakarta: Gramedia Widiasarana.

Ikatan Akuntan Indonesia (IAI). (2018). Standar Akuntansi Keuangan 2018 Jakarta: Ikatan Akuntansi Indonesia.

Indayani, V. (2017). Pengaruh Fdr, Roa, Roe, terhadap Perubahan Laba Perusahaan di Bei (2011-2015). Skripsi. Jakarta: Program Studi Perbangkan Syariah Fakultas Ekonomi dan Bisnis Universitas Islam Negeri Syarif Hidayatullah Jakarta.

Kasmir, J. (2017). Analisis Laporan Keuangan. Jakarta: Raja Grafindo Persada.

Kurniawati, W. (2016). Prediksi Laba di Masa yang akan Datang dengan Rasio Keuangan pada Perusahaan Manufaktur yang Terdaftar di Bursa Efek Indonesia. Jurnal Perilaku dan Strategi bisnis. Vol. 4 No. 1 ISSN:2337-5817. (Desember) 2016. Bandung: Program Studi Manajemen Keuangan Fakultas Ekonomi \& Bisnis Universitas Mercu Buana

Martunis, G. S. (2013).Pengaruh Opm Roa dan Roe terhadap Perubahan Laba Perusahaan di Bursa Efek Indonesia. Jurnal Akuntansi dan Keuangan. Vol. 5 No. 1 ISSN: 2301- 4717 (Juli) 2013. Aceh: Program Studi Manajemen Fakultas Ekonomi dan Bisnis Universitas Malikulsaleh Lhokseumawe.

Mohd, K., \& Zaharudin, K. (2019). Future Earnings Growth and Dividend Payout: Evidence from Malaysia. Journal Management Science Letters, Vol. 9 Issue. 2 pp. 347-356 ISSN: 1923-9335 (November) 2019. Kedah: Departement Finance and Banking Faculty School of Economic Utara Malaysia University.
Pradani, I. A., (2018). Pengaruh Rasio Keuangan terhadap Pertumbuhan Laba pada Perusahaan Asuransi. Skripsi. Surabaya: Program Studi Akuntansi Fakultas Ekonomi dan Bisnis Islam Universitas Islam Negeri Sunan Ampel.

Prasetyo, A. H. (2011). Manajemen Keuangan bagi Manajer Non Keuangan Jakarta: Sekolah Tinggi Manajemen PPM.

Safitri, A. M., \& Mukaram, M. (2018). Pengaruh ROA, ROE, dan NPM terhadap Pertumbuhan Laba pada Perusahaan Sektor Industri Barang Konsumsi yang terdaftar di Bursa Efek Indonesia. Jurnal Riset Bisnis \& Investasi Vol. 4, No. 1 ISSN: 2460-8211 (April) 2018. Bandung: Program Studi Administrasi Niaga Politeknik Negeri Bandung.

Santoso, S. (2012). Panduan Lengkap SPSS Versi 20. Jakarta: Elex Media Komputindo.

Sartono, A. (2010). Menejemen Keuangan Teori dan Aplikasi. (Edisi Keempat). Yogyakarta: Bhakti Profesindo Yogyakarta.

Simatupang, R. A. D., (2018). Pengaruh Rasio Likuiditas dan Profitabilitas terhadap Laba pada Ptpn Iii Medan. Skripsi. Medan: Program Studi Manajemen Fakultas Ekonomi dan Bisnis Universitas Medan Area.

Sugiyono, (2012). Metode Penelitian Bisnis. Bandung: Alfabeta.

Supardi, (2013). Aplikasi Statistika dalam Penelitian Konsep Statistika yang Lebih Komprehensif. Jakarta: Change Publication.

Syamsuddin, L., (2018). Manajemen Keuangan Perusahaan. Jakarta: RajaGrafindo Persada

Wardiningsi, S. S., \& Susanti, R., (2017). Pengaruh Modal Kerja, Aset, dan Omzet Penjualan terhadap Laba Ukm Catering di Wilayah 
Surakarta. Jurnal Perilaku dan Strategi Bisnis. Vol. 5, No.1, ISSN: 2614-7289. (Februari) 2017. Surakarta: Program Studi Manajemen Fakultas Ekonomi Universitas Slamet Riyadi Surakarta.

Wild, J. J., Subramanyam, K. R., \& Halsey, R. F. (2017). Analisis Laporan Keuangan (Dewi Yanti, Penerjemah.). Jakarta: Salemba Empat.

Winarko, S. P., (2014). Pengaruh Modal Sendiri, Jumlah Anggota dan Aset terhadap Sisa Hasil Usaha pada Koperasi di Kota Kediri. Nusantara of Research. Vol. 1 No.2, ISSN: 2355-7249. (Oktober) 2014. Kediri: Program Studi Akuntansi Fakultas Ekonomi Universitas Nusantara PGRI Kediri.

www.arsenal.com/statmentoffinancial.

www. bisnis.com/bola/catatan sepakbola: defisit itu jelas menakutkan, diakses pada (25 Agustus 2019, $10.00 \mathrm{WIB})$.

www.bisnis.com/bola/liga inggris: arsenal umumkan kenaikan keuntungan, di akses pada (27 maret 2019. 12.00 WIB). www. cnbcIndonesia.com/news/atur hak siar klub liga premier inggris cetak laba Rp 19,8 T, diakses pada (26 Maret 2019, 08.09 WIB).

www.deloitte.com./uk/en/pages/sport business group/articles/annual review of football finance, diakses pada (17 Februari 2019, 09.20 WIB).

www.detik.com/sport/sepakbola sebagai anomali bisnis, diakses pada (25 maret 2019, 15.00 WIB).

www.fifa.com./fifa world rangking, diakses pada (18 Februari 2019, $12.00 \mathrm{WIB})$.

www.financialfootballnews.com/arsenal 2018 financial review wenger out cash still in, diakses pada (8 Agustus 2019, 10.00 WIB).

www.iasplus.com/en/standards, Maret 2019, 08.09 WIB).

www.premierleague.com/club, diakses pada (23 Februari 2019, 13.00 WIB).

www. tempo.com/bola/naik turun arsenal 22 tahun diasuh wenger klub tak pernah rugi, diakses pada (8 Agustus 2019, 10.11 WIB). 